\title{
PENGARUH PENAMBAHAN DL-METIONIN DALAM MEDIA KULTIVASI TERHADAP PRODUKSI SEFALOSPORIN C DARI KAPANG Acremonium chrysogenum CB2/11/1
}

\section{INFLUECE OF ADDITION DL-METIONIN IN CULTIVATION MEDIUM TO PRODUCE CEPHALOSPORIN C FROM FUNGI Acremonium chrysogenum CB2/11/1}

\author{
Eni Dwi Islamiati ${ }^{1 *}$, Khaswar Syamsu ${ }^{1}$, Erwahyuni E Prabandani ${ }^{2}$ \\ ${ }^{1}$ Jurusan bioteknologi Institut Pertanian Bogor \\ ${ }^{2}$ Balai Pengkajian Bioteknologi - Badan Pengkajian dan Penerapan Teknologi Serpong \\ *Corresponding author: enidwiislamiati@gmail.com
}

\begin{abstract}
Abstrak
Sefalosporin merupakan antibiotik $\beta$-laktam yang mempunyai efektivitas dalam melawan bakteri Gram positif dan negatif. Antibiotik ini dihasilkan oleh kapang Acremonium chrysogenum. Media kultivasi yang optimum dapat meningkatkan produksi sefalosporin. Komposisi media kultivasi yang paling berpengaruh adalah induser. Induser dapat meningkatkan produksi sefalosporin dari kapang A. chrysogenum. Penelitian ini bertujuan untuk melihat pengaruh metionin dalam media produksi sefalosporin dari kapang $A$. chrysogenum CB 2/11/1. Inokulum A.chrysogenum dibiakkan pada media kultivasi sefalosporin tanpa penambahan DL-metionin dan pada media kultivasi dengan penambahan DL-metionin. Penentuan level konsentrasi DL-metionin dirancang menggunakan Rancangan Acak Lengkap 1 faktor pada tiap-tiap proses penentuan nutrisi. Data yang diperoleh dari masing-masing perlakuan dianalisis sidik ragam pada taraf nyata $5 \%$. Hasil penelitian menunjukkan bahwa metionin sebagai induser dapat meningkatkan produksi sefalosporin sebesar 1,2 kali dibandingkan dengan media kultivasi yang tanpa menggunakan metionin. Pada pengujian level konsentrasi DL-metionin menunjukkan bahwa konsentrasi terbaik metionin adalah $0,4 \mathrm{~g} / \mathrm{L}$ menghasilkan sefalosporin sebesar $3989 \mathrm{mg} / \mathrm{L}$.
\end{abstract}

Kata kunci: Kultivasi; Metionin; Sefalosporin

\begin{abstract}
Cephalosporins is a $\beta$-lactam antibiotic that has effectiveness against Gram-positive and negative bacteria. This antibiotic is produced by Acremonium chrysogenum. Optimum cultivation medium can increase the production of cephalosporins. The most influential cultivation medium composition is an inducer that increases production of cephalosporin from the fungi. The objective of this study was to investigate the influence of methionine in the cephalosporin production medium containing A. chrysogenum CB 2/11/1, with DL-methionine as the inducer. The inoculum was cultivated in the cultivation media containing cephalosporins without the addition of DL-metionin and in the media with the addition of DL-metionin. The result showed that the DL-methionine increased cephalosporins production 1.2 fold compared to those without using methionine. The assay on the concentration level of DL-methionine showed the best concentration methionine of $0.4 \mathrm{~g} / \mathrm{L}$ produced cephalosporin by $3989 \mathrm{mg} / \mathrm{L}$.
\end{abstract}

Keywords: Cephalosporin; Cultivation; DL-Methionine

Permalink/DOI: http//:dx.doi.org/10.15408/kauniyah.v10i1.3595 


\section{PENDAHULUAN}

Sefalosporin merupakan antibiotik golongan $\beta$-laktam yang bekerja menghambat sintesis dinding sel bakteri. Efektivitasnya terhadap bakteri Gram positif dan negatif lebih unggul jika dibandingkan antibiotik dari golongan $\beta$-laktam yang lainnya (Ruiz et al., 2010). Berdasarkan penemuannya sefalosporin C merupakan contoh sefalosporin yang paling awal ditemukan. Fungsinya sebagai antibiotik yang cukup potensial menjadikannya produk antibiotik yang banyak dihasilkan setelah penisilin. Berbagai senyawa sefalosporin semisintetik dengan sifat yang berbeda-beda dapat diperoleh dengan cara mengubah gugus samping dari sefalosporin C (Yin et al., 2011).

Kelebihan sefalosporin dibandingkan penisilin yang termasuk dalam golongan $\beta$ laktam yaitu mampu menghambat pertumbuhan bakteri Gram positif dan negatif (Kresse et $a l ., 2007)$. Selain itu sefalosporin lebih resisten terhadap enzim beta laktamase yang dihasilkan bakteri untuk menghambat kerja penisilin (Agbor et al., 2011). Berdasarkan kelebihan yang dimiliki menyebabkan sefalosporin dibutuhkan dalam jumlah yang lebih besar.

Kapang A. chrysogenum merupakan salah satu penghasil sefalosporin. Untuk menghasilkan sefalosporin dalam jumlah maksimum, kapang membutuhkan nutrisi di dalam media kultivasi. Nutrisi yang dibutuhkan kapang sangat komplek diantaranya dibutuhkan sumber karbon, nitrogen, dan beberapa macam asam amino di dalam media kultivasi (Srivastava et al., 2006). Selain itu di dalam media kultivasi juga dibutuhkan induser yang berfungsi untuk mengoptimumkan produksi sefalosporin (Cuadra et al., 2008). Hal ini karena media kultivasi yang optimum sangat berpengaruh dalam setiap fase pertumbuhan kapang.

Sefalosporin secara optimum dihasilkan pada saat kapang A. chrysogenum mencapai fase pembentukan arthrospora (Muniz et al., 2007). Arthrospora yang terdapat dalam fase stasioner merupakan pembengkakan hifa, sefalosporin maksimal diproduksi (Oijikas et al., 2010). Untuk mempercepat kapang mencapai fase tersebut, dibutuhkan induser yang mampu menginduksi pembentukan arthrosopra (Schmitt et al., 2004). DL-metionin merupakan salah satu asam amino yang umum digunakan untuk menginduksi beberapa kapang dalam meningkatkan hasil produksi, seperti yang dilakukan oleh Bok et al. (2011) menggunakan DL-metionin dalam produksi tanin yang digunakan sebagai induser untuk menginduksi peningkatan produksi. Oleh karena itu, perlu diteliti lebih lanjut apakah terdapat pengaruh penambahan DL-metionin dalam media kultivasi terhadap produksi sefalosporin serta batas penambahan DL-metionin dalam media kultivasi untuk menghasilkan sefalosporin dalam jumlah maksimal.

\section{MATERIAL DAN METODE}

Bahan yang digunakan dalam penelitian ini adalah isolat kapang $A$. chrysogenum CB2/11/1 yang merupakan kultur koleksi Balai Pengkajian Bioteknologi-Badan Pengkajian dan Penerapan Teknologi (BPB-BPPT) Serpong, Tangerang Selatan. Molases, malto dekstrin, sukrosa dan minyak sawit dan glukosa sebagai sumber karbon, sedangkan urea, ammonium sulfat, yeast ekstrak dan corn step liquor sebagai sumber nitrogen, $\mathrm{MgSO}_{4} .7 \mathrm{H}_{2} \mathrm{O}, \mathrm{CaCO}_{3}$, parafin, minyak kedelai dan DL-metionin.

\section{Penyiapan Inokulum}

Kapang A. chrysogenum CB2/11/1 dalam agar miring berumur 10 hari disuspensi dengan $6 \mathrm{~mL}$ garam fisiologis, kemudian sebanyak 0,5 $\mathrm{mL}$ diinokulasi pada media seed culture. Media seed culture yang telah dinokulasi kemudian diinkubasi pada inkubator kocok dengan agitasi $220 \mathrm{rpm}$, suhu $28^{\circ} \mathrm{C}$ selama 72 jam. Inokulum selanjutnya digunakan sebagai starter untuk media kultivasi.

\section{Komposisi Media Kultivasi Sefalosporin tanpa Penambahan DL-Metionin (Farmitalia, 2001)}

Media basal untuk produksi sefalosporin terdiri dari $50 \mathrm{~g} / \mathrm{L}$ malto dekstrin, $110 \mathrm{~g} / \mathrm{L}$ CSL, $9 \mathrm{~g} / \mathrm{L}$ ammonium sulfat, 2,1 g/L urea, 5,6 $\mathrm{g} / \mathrm{L} \quad \mathrm{MgSO}_{4} \cdot 7 \mathrm{H}_{2} \mathrm{O}, \quad 10 \mathrm{~g} / \mathrm{L} \quad \mathrm{CaCO}_{3}, 4 \mathrm{~g} / \mathrm{L}$ parafin dan $10 \mathrm{~g} / \mathrm{L}$ trace element kemudian disterilisasi selama 25 menit pada suhu $121^{\circ} \mathrm{C}$.

\section{Komposisi Media Kultivasi Sefalosporin dengan Penambahan DL-Metionin (Farmitalia, 2001)}

Media basal untuk produksi sefalosporin terdiri dari $50 \mathrm{~g} / \mathrm{L}$ malto dekstrin, $110 \mathrm{~g} / \mathrm{L}$ 
CSL, $9 \mathrm{~g} / \mathrm{L}$ ammonium sulfat, 2,1 g/L urea, 5,6 $\mathrm{g} / \mathrm{L} \quad \mathrm{MgSO}_{4} .7 \mathrm{H}_{2} \mathrm{O}, \quad 10 \mathrm{~g} / \mathrm{L} \quad \mathrm{CaCO}_{3}, 4 \mathrm{~g} / \mathrm{L}$ parafin dan $10 \mathrm{~g} / \mathrm{L}$ trace element kemudian disterilisasi selama 25 menit pada suhu $121^{\circ} \mathrm{C}$. Setelah disterilisasi ditambahkan $0,5 \mathrm{~g} / \mathrm{L}$ DLmetionin.

\section{Proses Kultivasi}

Inokulum hasil inkubasi pada media seed culture diinolukasikan sebanyak $10 \%$ ke dalam media kultivasi, setelah itu media kultivasi diinkubasi pada inkubator kocok dengan agitasi $220 \mathrm{rpm}$, suhu $25^{\circ} \mathrm{C}$ selama 120 jam.

\section{Panen Ekstrak Kasar dan Analisis Kadar Sefalosporin (Farmitalia, 2001)}

Panen dilakukan dengan cara sentrifugasi kaldu hasil kultivasi sefalosporin sebanyak 10 mL pada kecepatan $3000 \mathrm{rpm}$ selama 20 menit pada suhu $4{ }^{\circ} \mathrm{C}$. Supernatan diambil sebagai ekstrak kasar dan disentrifugasi kembali pada kecepatan $15000 \mathrm{rpm} 4{ }^{\circ} \mathrm{C}$ selama 15 menit dengan tujuan mengurangi pengotor yang terdapat dalam ekstrak. Supernatan yang terbentuk dianalisis dengan menggunakan Kromatografi Cair Kinerja Tinggi (KCKT). Metode KCKT yang digunakan yaitu $\mathrm{KH}_{2} \mathrm{PO}_{4}$ dan metanol sebagai fase gerak dengan perbandingan sebesar 55:45\%. Detektor Photo Dioda Array (PDA) UV vis pada $\lambda 254 \mathrm{~nm}$ dan kolom C-18 (4.6 x $150 \mathrm{~mm})$.

\section{Penentuan Konsentrasi DL-Metionin}

Konsentrasi DL-metionin yang diuji dalam media kultivasi antara lain 0,$1 ; 0,2 ; 0,3$; 0,$4 ; 0,5 ; 0,6 ; 0,7 ; 0,8 ; 0,9$ g/L. Masing-masing konsentrasi DL-metionin yang telah ditentukan ditambahkan dengan komposisi media kultivasi yang lain yaitu $50 \mathrm{~g} / \mathrm{L}$ malto dekstrin, $110 \mathrm{~g} / \mathrm{L}$ corn step liquor, 2,1 g/L urea, ammonium sulfat $5 \mathrm{~g} / \mathrm{L}, 5,6 \mathrm{~g} / \mathrm{L} \mathrm{MgSO}_{4} \cdot 7 \mathrm{H}_{2} \mathrm{O}$, $10 \mathrm{~g} / \mathrm{L} \mathrm{CaCO} 3,4 \mathrm{~g} / \mathrm{L}$ parafin dan $10 \mathrm{~g} / \mathrm{L}$ trace element.

Penentuan level konsentrasi DL-metionin dirancang menggunakan Rancangan Acak Lengkap (RAL) 1 faktor pada tiap-tiap proses penentuan nutrisi. Data yang diperoleh dari masing-masing perlakuan dianalisis sidik ragam (ANOVA). Apabila hasilnya menunjukkan perbedaan yang nyata, analisis akan dilanjutkan dengan uji t pada taraf 5\% menggunakan software Minitab 14.

\section{HASIL}

Pertumbuhan kapang A. chrysogenum dalam media kultivasi dapat dilihat melalui perkembangan bentuk morfologinya. Seperti terlihat pada Gambar 3. Kapang yang ditumbuhan pada media kultivasi tanpa tambahan DL-metionin menunjukkan bentuk hifa yang cenderung lebih kecil dibandingkan morfologi kapang yang ditumbuhkan pada media kultivasi yang ditambahkan DLmetionin (Gambar 3) yang cenderung lebih besar. Pengamatan dilakukan menggunakan mikroskop cahaya dengan perbesaran 10 x 40 .

Media yang sebelumnya telah dilihat morfologi kapang hasil kultivasi, kemudian dilanjutkan pengujian kadar sefalosporin terhadap pengaruh perlakukan media. Hasil pengujian konsentrasi sefalosporin menggunakan analisis KCKT. Penentuan kadar sefalosporin menggunakan sefalosporin murni komersial yang dibuat dalam kurva standar dengan konsentrasi yang dibuat dari jarak 0 mg/L sampai dengan konsentrasi 3000 mg/L.

Hasil perlakuan media kultivasi tanpa penambahan DL-metionin dalam menghasilkan sefalosporin terdeteksi pada waktu retensi 3 menit dengan serapan gelombang 214-532 $\mathrm{nm}$. Berdasarkan hasil kromatogram didapatkan banyak puncak, hal ini terjadi karena didalam media kultivasi terdapat beragam senyawa. Puncak tertinggi terdapat pada menit ke-3 yang menunjukkan sefalosporin yang dihasilkan oleh media kultivasi perlakuan tanpa penambahan DL-metionin (Gambar 4).

Berdasarkan hasil analisis KCKT, konsentrasi sefalosporin dari media kultivasi tanpa tambahan DL-metionin (Gambar 4) didapatkan luas area 1,2 kali lebih rendah jika dibandingkan konsentrasi sefalosporin yang berasal dari media kultivasi dengan penambahan DL-metionin (Gambar 5). Konsentrasi sefalosporin dengan perlakuan media menghasilkan perbedaan konsentrasi $3289 \mathrm{mg} / \mathrm{L}$ dalam media tanpa penambahan DL-metionin dan $3989 \mathrm{mg} / \mathrm{L}$ pada media dengan penambahan DL-metionin.

Penentuan level konsentrasi DL-metionin dilakukan untuk mengetahui batas toleransi penggunaan metionin dalam media kultivasi untuk produksi sefalosporin. Pada pengujian konsentrasi (Gambar 6) level penggunaan DLmetionin yang diberikan bervariasi yaitu antara 
0,1 g/L sampai dengan $0,9 \mathrm{~g} / \mathrm{L}$ ke dalam masing-masing media kultivasi. Setelah dilakukan pengujian, didapatkan metionin konsentrasi $0,4 \mathrm{~g} / \mathrm{L}$ menghasilkan sefalosporin tertinggi. DL-metionin dalam metabolisme kapang A. chrysogenum berfungsi sebagai sumber sulfur, jika sulfur dalam media jumlahnya sedikit akan mengganggu metabolisme. Dalam jumlah berlebih sulfur dalam media akan berubah menjadi senyawa racun.
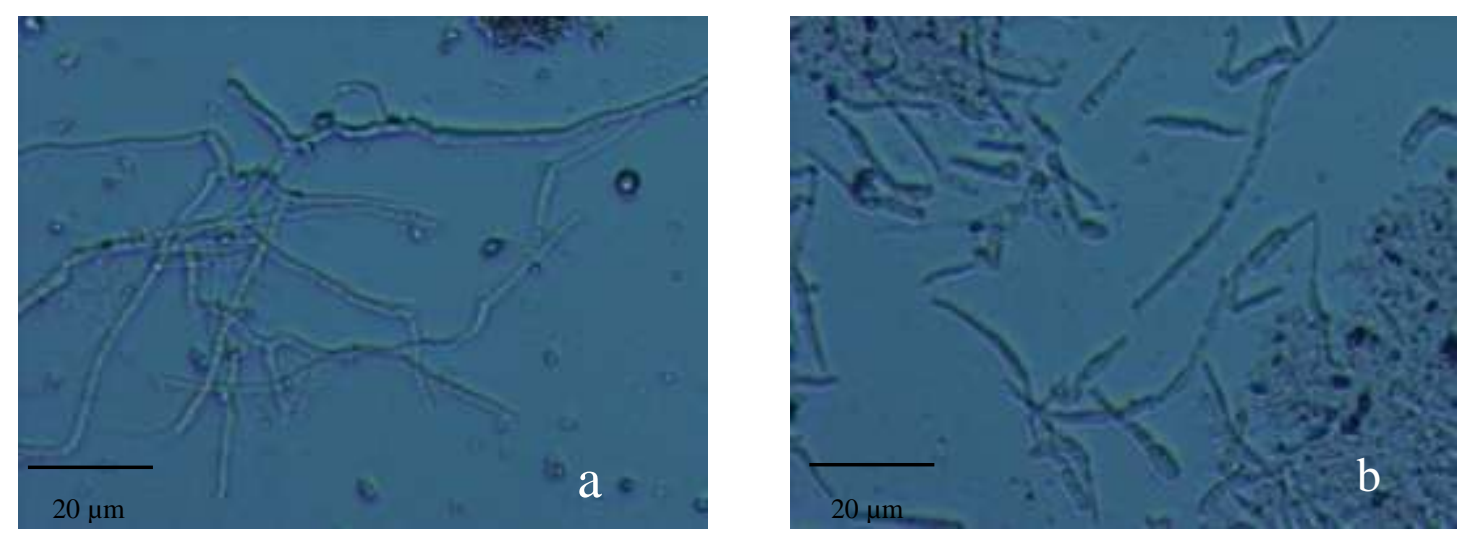

Gambar 3. Morfologi kapang A. chrysogenum CB 2/11/1 pada media kultivasi a) Tanpa penambahan DL-metionin b) Dengan penambahan DL-metionin

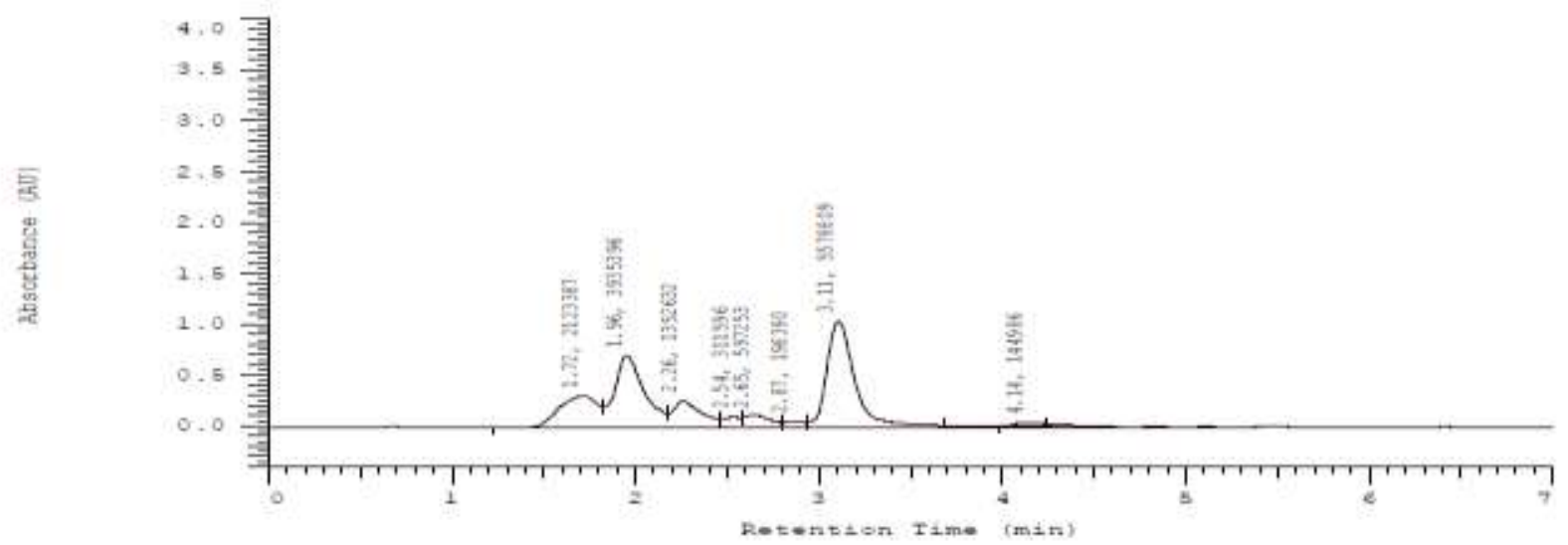

Gambar 4. Hasil analisis kromatografi kandungan sefalosporin dari media kutivasi tanpa penambahan DL-metionin

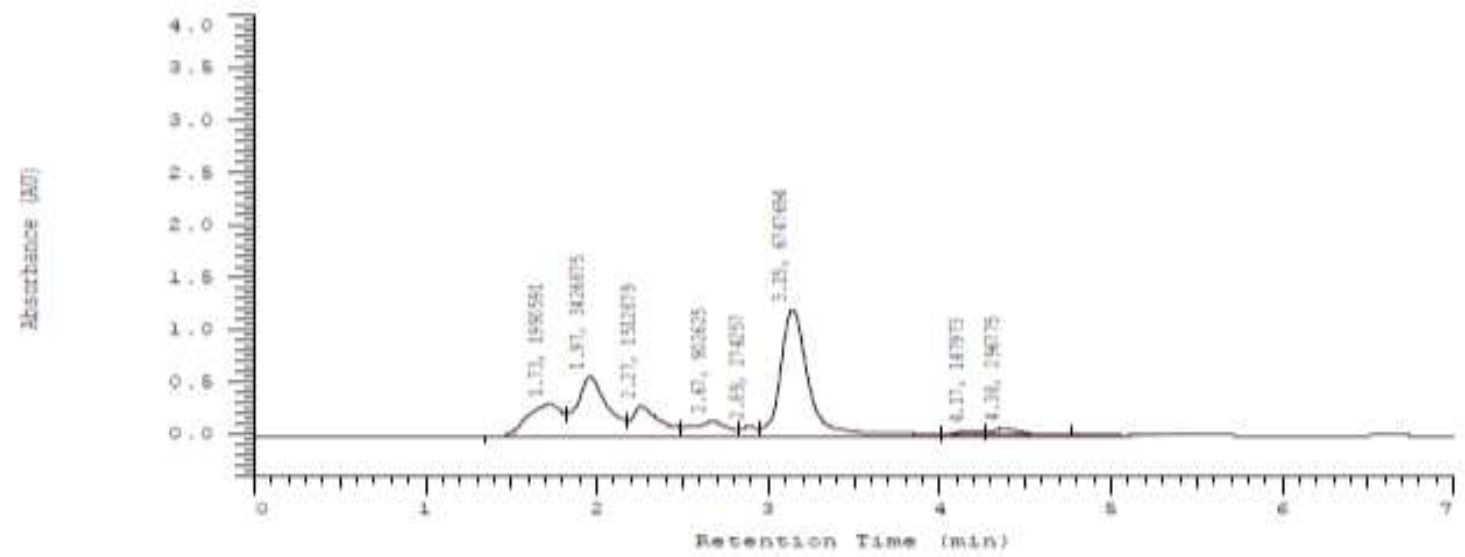

Gambar 5. Hasil analisis kromatrografi kandungan sefalosporin dari media kultivasi dengan penambahan DL-metionin 


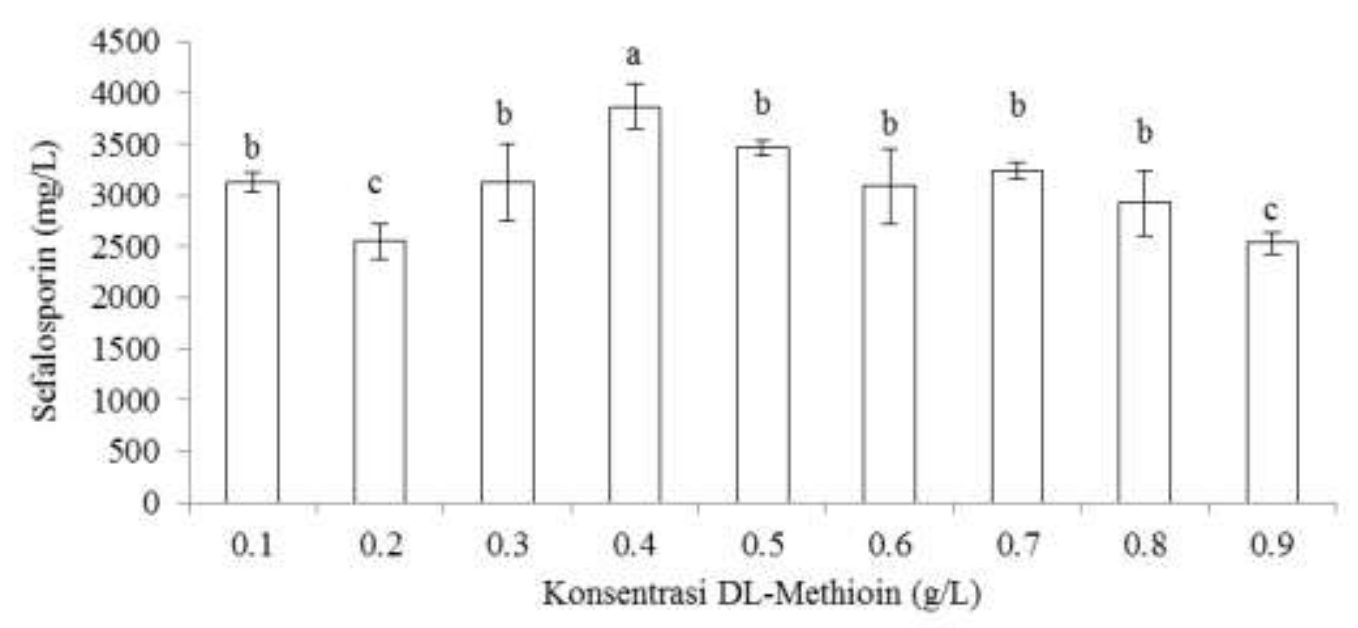

Gambar 6. Pengaruh level konsentrasi DL-metionin terhadap produksi sefalosporin. Huruf yang berbeda menunjukkan beda nyata perlakuan pada taraf uji $5 \%$

\section{PEMBAHASAN}

\section{Pertumbuhan Kapang A. chrysogenum dalam Media Kultivasi}

Pertumbuhan mikroorganisme sangat mempengaruhi produk yang akan dihasilkan. Pengamatan terhadap fase pertumbuhan sangat diperlukan, hal ini dilakukan karena pada saat kapang memproduksi produk yang kita inginkan diketahui, maka fase-fase yang lain dapat dipercepat ataupun fase produksi dapat dipertahankan agar produk yang dihasilkan dalam jumlah optimum (Duan et al., 2011). Penelitian serupa dilakukan oleh (Naganagouda et al., 2008 dan Mochtarani et al., 2010) keduanya sangat memperhatikan fase pertumbuhan kapang Aspergilus oryzae.

Berdasarkan kurva pertumbuhan kapang A. chrysogenum diketahui produksi sefalosporin berada di fase stationer, maka di dalam media ditambahkan senyawa yang dapat mempercepat fase pertumbuhan. Salah satu senyawa yang dapat mempercepat fase pertumbuhan adalah DL-metionin. DL-metionin di dalam media berfungsi sebagai penginduksi hifa untuk lebih besar sehingga fase pertumbuhan lebih cepat. Hal ini bertujuan untuk membuat kapang lebih cepat memasuki fase stasioner yang ditandai dengan pembengkakan hifa dalam memproduksi sefalosporin.

Kapang A. chrysogenum dalam proses pembentukan hifa membutuhkan asupan nitrat untuk dapat tumbuh membesar dan menghasilkan sefalosporin dalam jumlah optimum. Hal ini sesuai dengan penelitian Zusuki et al. (2009) bahwa nitrat mempengaruhi pembengkakan hifa sehingga mempercepat kapang $A$. chrysogenum memasuki fase stasioner ketika sefalosporin optimum dihasilkan.

Cao et al. (2013) menyatakan bahwa antibiotik yang termasuk metabolit sekunder dihasilkan pada fase stasioner, dimana pada fase stasioner antibiotik dihasilkan dengan jumlah tertinggi. Pertumbuhan kapang pada fase stasioner ditandai dengan perubahan morfologi hifa kapang menjadi bentuk arthrospora (Wieman et al., 2011). Hal ini menjadi acuan bahwa dengan seiring dengan pembengkakan yang terjadi pada hifa menandakan hasil metabolit sekunder yaitu antibiotik sefalosporin semakin tinggi.

DL-metionin pada media kultivasi kapang A. chrysogenum berfungsi sebagai sumber sulfur. Selain sebagai sumber sulfur, menurut Martian (2012) DL-metionin dalam media produksi sefalosporin juga mempunyai fungsi sebagai penginduksi enzim yang berperan dalam jalur biosisntesis sefalosporin. Selain itu DL-metionin juga berfungsi menstimulasi kapang $A$. chrysogenum dalam pembentukan arthrospora yaitu fase sefalosporin optimum dihasilkan.

\section{Pengujian Perlakuan Media terhadap Konsentrasi Sefalosporin}

Perbedaan perlakuan media mempengaruhi sefalosporin yang dihasilkan oleh kapang A. chrysogenum, maka dari itu perlu dilakukan pengujian kadar sefalosporin yang dihasilkan. Metode pengujian kadar sefalosporin menurut $\mathrm{Lu}$ et al. (2006) yang akurat yaitu menggunakan KCKT. Pengujian dengan metode KCKT membutuhkan penggunaan kurva 
standar, yang digunakan untuk mengkonversi luas area yang didapat untuk menentukan konsentrasi sefalosporin yang dihasilkan (Sokolova et al., 2012). Area puncak pada KCKT diukur melalui integrasi sinyal elektronik dari detektor. Luas area proporsional dengan konsentrasi senyawa yang uji (Hedhammar et al., 2013).

Pengujian menggunakan kromatografi cair kinerja tinggi didasarkan pada panjang gelombang serapan serta waktu retensi pada menit ke-3. Hal ini sesuai dengan prinsip kromatografi kolom bahwa senyawa yang terelusi merupakan senyawa yang larut dengan eluen yang digunakan. Jumlah senyawa sefalosporin yang mengacu pada kurva standar yang telah dibuat sehingga dapat dipastikan senyawa yang dihasilkan oleh kapang $A$. chrysogenum adalah sefalosporin karena puncak yang muncul ada pada menit yang sama.

Perbedaan konsentrasi sefalosporin dalam media yang diberikan penambahan DLmetionin dan tanpa penambahan sangat signifikan. Hal ini karena DL-metionin dalam media kultivasi berfungsi sebagai sumber sulfur dalam proses pembentukan sefalosporin, selain itu juga berfungsi sebagai penginduksi Isopenisilin $\mathrm{N}$ sintetase (Pichichero et al., 2006).

Biosintesis sefalosporin $\mathrm{C}$ dimulai dari kondensasi tiga asam amino, asam L- $\alpha$ aminodipik, L-sistein, dan L-valin, untuk membentuk tripeptida (L- $\alpha$-amoniadipyl)-Lsisteinil-D-valin (LLD-ACV) dengan menggunakan enzim ACV sintetase. Tripeptida LLD-ACV kemudian dibuat siklik untuk membentuk inti penam (penam nucleus), isopenisilin $\mathrm{N}$, dengan enzim isopenisilin $\mathrm{N}$ sintetase atau siklase (Cheng et al., 2013). Pada saat inilah peran sulfur yang dihasilkan metionin menginduksi enzim isopenisilin sintetase dalam proses siklikasi.

\section{Pengujian Level Konsentrasi DL-Metionin untuk Produksi Sefalosporin pada $A$. chrysogenum}

DL-Metionin pada media kultivasi kapang A. chrysogenum berfungsi sebagai sumber sulfur sehingga ketika jumlah yang digunakan sesuai dengan kebutuhan kapang DL-metionin akan menginduksi produksi sefalosporin, tetapi ketika jumlahnya berlebihan akan berubah menjadi racun (Holker et al., 2004). Hal ini terjadi karena DL-metionin yang awalnya digunakan sebagai sumber sulfur akan direduksi menjadi sulfida. Akumulasi jumlah sulfida akibat perombakan DLmetionin akan disimpan dalam bentuk sulfur oksida yang bersifat racun bagi kapang. Racun dalam bentuk sulfur oksida yang menghambat produksi sefalosporin.

DL-metionin dalam biosintesis sefalosporin digunakan sebagai sumber sulfur yang akan menginduksi enzim yang berperan dalam jalur pembentukan sefalosporin. Selain itu DLmetionin juga berfungsi menstimulasi kapang A. chrysogenum dalam pembentukan arthrospora yaitu fase sefalosporin optimum dihasilkan. Pengujian level DL-metionin ini adalah tahapan yang sangat penting, agar diketahui batas toleransi penggunaannya dalam media kultivasi. Penggunaan yang tepat akan menginduksi terbentuknya sepalosporin lebih tinggi, tetapi jika di dalam media DL-metionin dengan jumlah berlebih yang terjadi penghambatan produk oleh substrat (Martian, 2012).

Penggunaan DL-metionin dalam jumlah tepat terbukti dapat meningkatkan produksi sefalosporin. Hal ini disebabkan metionin yang digunakan sebagai induser dalam media kultivasi, hanya digunakan sebagai sumber sulfur untuk menginduksi enzim dalam pembentukan sefalosporin. Jika jumlah DLmetionin berlebihan setelah digunakan sebagai induksi, sisa sulfur yang tidak digunakan akan terakumulasi dan disimpan dalam bentuk sulfur oksida. Sulfur oksida tidak dapat diurai oleh kapang, bahkan dapat membuat kapang mengalami penyusutan bobot massa kapang sebagai efek lain dari penggunaan DLmetionin secara berlebihan (Lee et al., 2010).

\section{KESIMPULAN}

DL-metionin sebagai induser yang ditambahan dalam media kultivasi terbukti dapat meningkatkan produksi sefalosporin sebesar 1,2 kali dibandingkan produksi sefalosporin yang dikultivasi dalam media tanpa penambahan DL-metionin yaitu menghasilkan konsentrasi sefalosporin sebesar $3989 \mathrm{mg} / \mathrm{L}$.

\section{UCAPAN TERIMA KASIH}

Penulis mengucapkan terima kasih kepada BPB-BPPT Serpong yang telah memberikan sarana bagi penulis dalam melakukan penelitian. 


\section{REFERENSI}

Agbor, V. O., Ma'ori, L., \& Opajobi, S. O. (2011). Bacterial resistance to cephalosporins in clinical isolates in Jos University Teaching Hospital (JUTH). New York Science, 22(4), 9-13.

Bok, J. W., Noordermeer, D., Kale, S. P. \& Keller, N. P. (2011) Secondary metabolic gene cluster silencing in Aspergillus nidulans. Molecular Microbiology, 2(61), 1636-1645.

Brakhage, A. A. (2012). Regulation of fungal secondary metabolism. Nature Microbiology, 89, 15-21.

Cao, K., Altaba, H., \& Kalama, K. (2013). Nitrogen source governs the pattern of growth and prostinamycein production in Streptomyces pristinaespiralis. Microbiology, 147, 2447-2459.

Cheng, S., Rhee, E. P., Sinha, S., Florez, J. C., Magnusson, M., Pierce, K. A, Souza, A. L., Clish, C. B., \& Gerszten, R. E. (2013). $\alpha$-Aminoadipic acid is a biomarker for diabetes risk. Clinicical of medicine, 10, 4309-4317.

Cuadra, T. Fernandez, F. J., Tomasini, A., \& Barrios, J. G. (2008). Influence of $\mathrm{pH}$ regulation and nutrient content oncephalosporin $\mathrm{C}$ production in solidstate fermentation by Acremonium chrysogenum C10. Applied Microbiology, 87, 216-220.

Duan, S., Guoqiang, Y., Yanli, Z., Hongfei, L., Weijia, N., \& Meina, S. (2011). Enhanced cephalosporin $\mathrm{C}$ production with a combinational ammonium sulfateand DO-Stat based soybean oil feeding strategy. Biochemical Engi neering, 6, 11-10. doi:10.1016/2011. 11.011.

Kar, B., Banarjee, R., \& Ramly, G. (2010). Biosynthesis of tannin acyl hydrolase from tannin-rich forest residue under different fermentation conditions. Indian Microbiology and Biotechnology, 25, 2938.

Kresse, H., Belsey, M. J., \& Rovini, H. (2007). The antibacterial drugs market. Nature Review Drug and Discovery, 6, 19-20.

Lee, M. S., Lim, J. S., Kim, C. H., Kyung, K., \& Suk, I. H. (2010). Effect of nutrient and culture conditions on morphology in the seed culture of Acremonnium chrysogenum ATCC 20339. Biotechnology and Bioprocess Enginering, 6, 156-160.

Lu, W., Kimball, E., \& Rabinowitz, J. D. (2006). A high-performance liquid chromatography mass spectrometry method forquantitation of nitrogencontaining intracellular metabolites. Mass Spectrometry, 7, 37-50.

Mandenius, C. F., Brundin. A., \& Lepholin. G. (2008). Bioprocess optimization using design of experiment methodology. Biotechnology, 24, 1191-1203.

Manfaati, R. (2010). Kinetika dan variabel optimum fermentasi asam laktat dengan media campuran tepung tapioka dan limbah cair tahu oleh Rhizopus oryzae (Tesis). Semarang. Universitas Diponegoro. 29-30.

Martian, J. F. (2012). Unraveling the metionin cephalosporin puzzle in Acremonium chrysogenum. Trends Biotechnology, 20, 502-507.

Mochtarani. B., Ramin. K., Mohammad H. A., \& Siavash D. M. (2010). Partitioning of Ciprofloxacin in aqueous two-phase system of poly (ethylene glycol) and sodium sulphate. Biochemistry and Enginering, 38, 241-247.

Muniz, C., Tania, E. C., Gabriela, R., \& Francisco, E. (2007). Penicllin and cephalosporin production: A Historical Perspective. Applied Microbiology, 49, 88-98.

Naganagouda. K., Alneysar. H., \& Mulimani. A. H. (2008). Aqueous two-phase extraction (ATPE): An attractive and economically viable technology for downstream processing of Aspergillus oryzae [alpha]-galactosidase. Process Biochemistry, 43, 1293-1299.

Ngili Y. (2009). Biokimia, Metabolisme dan Bioenergitika. Yogyakarta. Graha Ilmu. 86-89.

Ooijkas, L. P., Weber, F. J., Buitelaar, R. M., Tramper, J., \& Rinzema, A. (2010). Defined media and inert supports: their potential as solid-state fermentation production systems. Trends Biotechnology, 18, 356-360. 
Pichichero, M. E. (2006). Cephalosporins can beprescribed safely for Penicillinallergic patients. Family practice, 55e, 106-12.

Riadi, M. M. (2007). Production of glucoamylase by marine endophytic Aspergillus sp. Jan-25 under optimized solid-state fermentation conditions on agro residues. Australian Basic and Applied Science, 6, 41-54.

Ruiz, B., Adan, C., \& Angela, F. (2010). Production of microbial secondary metabolites: Regulation by the carbon source. Microbiology, 36, 146-167.

Schmitt, E. K., Hoff, B., Kuck, U. (2004). Regulation of sefalosporin biosynthesis. Advance Biochemistry and Biotechnology, 88, 1-43.

Srivastava, P., Mishra, P., \& Kundu, S. (2006). Process strategies for cephalosporin c fermentation. Science Industrial Research, 65, 599-602.

Sokolova, L. I., Chernyaev, A .P., \& Chera, E. T. (2012). Reversed-phase HPLC determination of antibiotics of the cephalosporin series in biological objects. Pharmacy and Chemistry, 36, 510.

Wiemann, P. (2011).FfVel1 and FfLae1, components of a velvet-like complex in Fusarium fujikuroi, affect differentiation and secondary metabolism. Molecular Microbiology, 24, 78-82. doi: 10.1111/j. 1365-2958. 07263.

Yin, W. \& Keller, N. P. (2011). Transcriptional regulatory elements in fungal secondary metabolism. Journal of Microbiology. 49, 329-339.

Zusuki H, Chinatsu M, Ishihara S, \& Hidehiko K. (2009). A Single Amino Acid Substitution Converts g-Glutamyltranspeptidase to a Class IV Cephalosporin Acylase (Glutaryl-7-Aminocephalosporanic Acid Acylase). Applied and environmentals microbiology, 17, 289291. doi: 10.1128/EM.70.10.6324-6328. 